\title{
The microbiome in inflammatory bowel diseases: from pathogenesis to therapy
}

\author{
Sheng Liu, Wenjing Zhao, Ping Lan ${ }^{\bowtie}$, Xiangyu Mou ${ }^{\bowtie}$ \\ Guangdong Provincial Key Laboratory of Colorectal and Pelvic Floor Diseases, The Sixth Affiliated Hospital, School of \\ Medicine, Sun Yat-sen University, Guangzhou 510275, China \\ $\bowtie$ Correspondence: lanping@mail.sysu.edu.cn (P. Lan), mouxy5@ms.sysu.edu.cn (X. Mou) \\ Received February 10, 2020 Accepted May 30, 2020
}

\begin{abstract}
Inflammatory bowel disease (IBD) has become a global disease with accelerating incidence worldwide in the 21st century while its accurate etiology remains unclear. In the past decade, gut microbiota dysbiosis has consistently been associated with IBD. Although many IBDassociated dysbiosis have not been proven to be a cause or an effect of IBD, it is often hypothesized that at least some of alteration in microbiome is protective or causative. In this article, we selectively reviewed the hypothesis supported by both association studies in human and pathogenesis studies in biological models. Specifically, we reviewed the potential protective bacterial pathways and species against IBD, as well as the potential causative bacterial pathways and species of IBD. We also reviewed the potential roles of some members of mycobiome and virome in IBD. Lastly, we covered the current status of therapeutic approaches targeting microbiome, which is a promising strategy to alleviate and cure this inflammatory disease.
\end{abstract}

KEYWORDS inflammatory bowel disease, pathogenesis, etiology, microbiome, dysbiosis, therapy

\section{INTRODUCTION}

Inflammatory bowel disease (IBD), including ulcerative colitis (UC) and Crohn's disease (CD), has become a global disease with accelerating incidence worldwide in the 21st century ( $\mathrm{Ng}$ et al., 2018). IBD is characterized by chronic immune-mediated intestinal inflammation that is driven by genetic susceptibility, environmental and microbial factors (Ni et al., 2017; Imhann et al., 2018).

Microbial factors have been historically proven to be indispensable for the onset of IBD (Alhagamhmad et al.,
2016) and advances in high-throughput sequencing has enabled us to elucidate the gut microbiome in IBD. Study of microbial etiology of IBD has been mainly focused on three directions: 1) the persistent pathogen theory 2) the excessive bacterial translocation theory and 3) the dysbiosis theory (De Hertogh et al., 2008; Kalischuk and Buret, 2010). The persistent pathogen theory hypothesizes IBD can be caused by persistent infection of an enteric pathogen like Mycobacterium avium subspecies paratuberculosis, Clostridium difficile, and adhesion-invasive Escherichia coli (AIEC). The excessive bacterial translocation theory suggests the excessive level of translocation of intestinal bacteria across the intestinal barrier is a cause of IBD. While, the dysbiosis theory hypothesizes that the shift of balance between "beneficial" vs. "detrimental" commensal bacteria can cause IBD.

The three theories are not mutually exclusive. For example, AIEC can be considered as both a persistent pathogen and detrimental commensal bacteria. The first two theories were comprehensively reviewed elsewhere (De Hertogh et al., 2008; Kalischuk and Buret, 2010); while in this review, we summarize the emerging evidences that imply the roles of dysbiosis in pathogenesis of IBD and the potential therapeutic options that target the gut microbiome to alleviate IBD.

\section{POTENTIAL ROLES OF DYSBIOSIS IN PATHOGENESIS OF IBD}

IBD is characterized by chronic immune-mediated intestinal inflammation that attacks the bowel. IBD has been consistently shown to be associated with gut dysbiosis (Kostic et al., 2014; Lynch and Pedersen, 2016). Although many IBD-associated dysbiosis have not been proven to be a cause or an effect of IBD, it is often hypothesized that at 
least some of alteration in microbiome is protective or causative.

Metagenomic studies have revealed microbial compositional changes in patients with IBD (Franzosa et al., 2019; Lloyd-Price et al., 2019) and metabolomic studies have revealed many defined microbial metabolites are depleted in individuals with IBD versus control individuals (Franzosa et al., 2019). Some of the depleted metabolites and related species are found to have anti-inflammatory effects and therefore are hypothesized to be protective; on the other hand, pro-inflammatory bacterial metabolites and species that are enriched in IBD patients are hypothesized to be causative, in terms of IBD.

In this review, we mainly focus on hypothesis that has both types of supporting evidences: 1) at least one association study in human IBD (rather than animal models); and 2) at least one pathogensis study in human, animal models, or cell models that explains the result in the association study.

\section{Potentially protective bacterial pathways and species}

The metabolic pathways encoded by the human gut microbiome produce numerous bioactive molecules that interact with the host. Typical bioactive molecules include shortchain fatty acids (SCFAs) and tryptophan derivatives that are produced by bacteria from dietary components, as well as secondary bile acids (BAs) that are bacteria-modified host products (Postler and Ghosh, 2017).

SCFAs (primarily acetate, propionate, and butyrate) produced by gut bacteria regulates protective immunity and reduces tissue inflammation (Furusawa et al., 2013; Kim et al., 2013). One study found that $12 \%$ of metabolic pathways were significantly different between IBD patients and healthy controls, and it confirmed a decrease in butanoate and propanoate metabolism genes in CD (Morgan et al., 2012). Another case-control analysis using shotgun metagenomic sequencing of stool samples from 1,792 individuals suggests the fermentation of pyruvate to butanoate, a butyrate precursor, was decreased in patients with IBD (Vich Vila et al., 2018). When looking at the bacterial species composition, a decreased amount of the commensal bacterium Faecalibacterium prausnitzii was reported in IBD patients compared with controls (Sokol et al., 2009; Hedin et al., 2016; Lloyd-Price et al., 2019). In vitro peripheral blood mononuclear cell stimulation by $F$. prausnitzii led to significantly lower IL-12 and IFN-y production levels and higher secretion of the anti-inflammatory cytokine IL-10 (Sokol et al., 2008b). Additionally, various F. prausnitzii isolates have abilities to simulate IL-10 secretion by dendritic cells (DCs) (Rossi et al., 2016), which suggests the anti-inflammatory role of $F$. prausnitzii in colitis. A $15 \mathrm{kDa}$ protein with anti-inflammatory properties, produced by $F$. prausnitzii, could alleviate colitis in mice by inhibiting the NF-kB pathway (Quevrain et al., 2016). Some F. prausnitzii strains are considered as candidates of next-generation probiotics (Martin et al., 2017).
Roseburia were also significantly reduced in IBD (Morgan et al., 2012), and IBD-genetic risk score was significantly associated with a decrease of Roseburia in healthy controls (Imhann et al., 2018). The depletion Roseburia hominis was observed in CD (Franzosa et al., 2019; Lloyd-Price et al., 2019) and UC (Machiels et al., 2014). In stool samples from patients with CD or UC, the strain abundance of Roseburia intestinalis decreased (Vich Vila et al., 2018). R. intestinalis are further reported as acetate-to-butyrate converters that reside in the intestinal mucus layer, where their anti-inflammatory effects may occur (Vich Vila et al., 2018).

In addition to reduced SCFA levels, decreased tryptophan metabolism levels were associated with a compromised epithelial barrier in IBD (Schirmer et al., 2019). Tryptophan can be converted by bacteria into bioactive indole-containing molecules that activate the aryl hydrocarbon receptor and down-regulates inflammation (Zelante et al., 2013). Indoleacrylic acid that promotes mucus production and suppresses inflammatory cytokine production was found reduced in patients with IBD (Wlodarska et al., 2017). Tryptophan-metabolizing pathways have been identified in some members of the human gut microbiota such as Clostridium sporogenes and E. coli (Williams et al., 2014; Dodd et al., 2017; Agus et al., 2018).

Primary BAs (PBAs) are produced by the host and then modified by bacteria into secondary BAs (SBAs) which mainly have anti-inflammatory activities. A normal bacterial BA metabolism plays an important role in modulating the host regulatory T (Treg) cell homeostasis (Song et al., 2020), as well as TH17 and Treg cell differentiation (Hang et al., 2019). Disrupted BAs metabolism has been observed in IBD patients, with fecal BAs pools skewed toward decreased SBAs and increased PBAs relative to healthy controls (Duboc et al., 2013; Franzosa et al., 2019). A more recent study also found that fecal BAs composition was altered (dominated by PBAs) in a sub-group of CD patients who did not sustain remission (Connors et al., 2019). PBAs cholate and its glycine and taurine conjugates were enriched in dysbiotic samples from participants with $C D$, and by contrast, the SBAs lithocholate and deoxycholate were reduced in dysbiosis (Lloyd-Price et al., 2019). Moreover, levels of lithocholic acid and deoxycholic acid (the most abundant gut SBAs), and genes required to convert PBAs to SBAs were reduced in stool from $U C$ relative to familial adenomatous polyposis (FAP) (Sinha et al., 2020). Members of the Roseburia and unclassified Subdoligranulum species were associated with BAs metabolism, and they were both markedly reduced in IBD (Lloyd-Price et al., 2019). Ruminococcaceae was reduced in IBD compared to healthy people (Vich Vila et al., 2018; Lo Presti et al., 2019; Yilmaz et al., 2019) and is known to contain members (particularly Clostridium leptum) capable of SBAs generation, which ameliorate intestinal inflammation in a process reliant on the TGR5 bile acid receptor (Sinha et al., 2020). Supplementation of SBAs also reduces intestinal inflammation in three murine colitis models (Sinha et al., 2020). 
Polysaccharide A (PSA) produced by Bacteroides fragilis directs the development of $\mathrm{CD}^{+}{ }^{+} \mathrm{T}$ cells and induces the anti-inflammatory function of Tregs (Mazmanian et al., 2005; Round et al., 2011). PSA protects animals from experimental colitis depending on IL-10-producing CD41 T cells (Mazmanian et al., 2008). Individuals with IBD had a significantly lower percentage of the $B$. fragilis population with PSA promoter orientated "ON" (Blandford et al., 2019). Moreover, sphingolipids produced by $B$. fragilis regulate homeostasis of host intestinal natural killer $\mathrm{T}$ cells and confer protection against oxazolone-induced experimental colitis (An et al., 2014).

Recent research on Akkermansia muciniphila revealed another potential protective pathway against IBD. Initially, a study of 46 IBD and 20 control patients showed that the abundance of Akkermansia muciniphila reduced many fold in CD and in UC (Png et al., 2010). Although a contradictory research indicated $A$. muciniphila was sufficient for promoting intestinal inflammation in both specific-pathogen-free and germ-free IL10(-/-) mice model of IBD (Seregin et al., 2017), in a follow-up study, A. muciniphila strain ATCC BAA835 was examined in gnotobiotic IL10(-/-) mice, and it did not promote short-term intestinal inflammation (Ring et al., 2019). A. muciniphila was shown to improve the gut barrier partially via its outer membrane protein Amuc_1100 that interacts with Toll-like receptor 2 (Plovier et al., 2017). The roles of $A$. muciniphila in modulating human immunological homeostatic was further demonstrated by the recent report that $A$. muciniphila induce homeostatic IgG production and antigen-specific $T$ cell responses in mice (Ansaldo et al., 2019) and that $A$. muciniphila treatment ameliorated Dextran Sulfate Sodium (DSS)-induced UC in mice (Bian et al., 2019).

\section{Potential causative bacterial pathways and species}

The integrated human microbiome project has revealed a few metabolites, notably nicotinuric acid, taurine, and acylcarnitines are more abundant in IBD patients than controls (Lloyd-Price et al., 2019). Interestingly, taurine has been previously identified as a mucosal inflammasome activator (Levy et al., 2015). Therefore, these metabolites were suggested as potential causative metabolites and therapeutic targets. The acylcarnitines-related species are Roseburia hominis, Klebsiella pneumoniae, Haemophilus parainfluenzae, and Clostridium bolteae (Lloyd-Price et al., 2019). Bacterial genes with virulence-related functions were enriched in IBD patients (Erickson et al., 2012; Morgan et al., 2012), presumably due to overgrowth of functionally altered commensals termed pathobionts. Escherichia coli revealed an increased amount in patients with IBD (Lloyd-Price et al., 2019; Pittayanon et al., 2019) and the adherent invasive E. coli (AIEC) pathovar are associated specifically with ileal mucosa in IBD (Darfeuille-Michaud et al., 2004; Sepehri et al., 2011), suggesting AIEC may contribute to IBD pathogenesis (Mylonaki et al., 2005; Garrett et al., 2010).
The frequent recovery of $E$. coli adhering to intestinal mucosa of patients with CD (Darfeuille-Michaud, 2002; Martin et al., 2004; Prorok-Hamon et al., 2014) and UC (Kotlowski et al., 2007) has stimulated great interest. Interaction of AIEC with intestinal mucosa in the context of IBD include: (1) AIEC cross the mucous layer and resist antimicrobial peptides; (2) AIEC adhere to intestinal epithelial cells (IECs) via FimH and carcinoembryonic antigen related cell adhesion molecule 6 (CEACAM6), and lead to colonisation of the gut mucosa; (3) AIEC enter lamina propria and Peyer's patches across $M$ cells via long polar fimbriae (LPF) expression, and interact with immune cells (Palmela et al., 2018). AIEC can promote inflammation, survive and replicate, and escape autophagy when inside macrophages (Bringer et al., 2006). Besides, AIEC also have the ability to evade the host immune response by suppressing IFN-Y mediated signal transducer and activator of STAT1 in IECs, preventing an appropriate antimicrobial response (Ossa et al., 2013). AIEC strain NC101 harbors the pks pathogenicity island that encodes the biosynthetic machinery for synthesizing the genotoxin colibactin (Nougayrede et al., 2006). Monocolonization with the commensal NC101 promoted invasive carcinoma and tumorigenesis in azoxymethane-treated IL-10(-/-) mice (Arthur et al., 2012; Eaton et al., 2018).

In a recent study, an Enterococcus faecium strain that has adhesion gene was isolated from the feces of UC patients, promotes colitis and colonic cytokine expression (Seishima et al., 2019). A previous research showed colonic inflammation in IL10(-/-) mice inoculated with Enterococcus faecalis and faecium strains is associated with gene expression changes similar to those of human IBD (Barnett et al., 2010).

Another pathobiont that associated with IBD is enterotoxigenic Bacteroides fragilis (ETBF) (Prindiville et al., 2000; Zamani et al., 2017). ETBF induces focal colonic Stat3 activation and Th17 immune responses and then promotes mucosal permeability (Wick et al., 2014; Chung et al., 2018; Dejea et al., 2018). Genes for $B$. fragilis toxin (bft) encode secreted oncotoxins, and increase IL-17 in the colon (Dejea et al., 2018). Besides promoting IBD, ETBF are also possibly driving FAP and CRC (Thiele Orberg et al., 2017; Garrett, 2019).

Campylobacter concisus is another adherent, invasive proteobacterium that has been associated with IBD (Zhang et al., 2009; Man et al., 2010; Mahendran et al., 2011; Mukhopadhya et al., 2011; Kirk et al., 2016; Underwood et al., 2016). Although the natural colonization site of C. concisus is oral cavity, C. concisus can also colonize the intestinal tract. Intestinal colonization by bacteria from the oral cavity has been suggested to be extensively involved in inflammatory diseases (Cao, 2017; Dickson, 2018). Some C. concisus strains acquired zonula occludens toxin (zot) gene from a phage, and increased intestinal membrane permeability by affecting the tight junctions (Zhang et al., 2014). C. concisus Zot may have enteric pathogenic potential by damaging intestinal epithelial barrier, inducing 
intestinal epithelial and macrophage production of proinflammatory cytokines in particular TNF- $\alpha$ (Mahendran et al., 2016), thus triggering the relapse of IBD. C. concisus cause epithelial sodium channel dysfunction via IL-32-regulated ERK1/2, as well as claudin-8-dependent barrier dysfunction, both of which contribute to $\mathrm{Na}(+)$ malabsorption and enteritis (Nattramilarasu et al., 2020).

Another oral cavity and gastrointestinal bacterium, Fusobacterium varium, may be one of the pathogenic factors in UC. F. varium bacteria were present at a higher abundance in the colonic mucosa of patients with UC compared to healthy controls (Ohkusa et al., 2002). When administered by rectal enema in mice, $F$. varium was able to cause colonic mucosal inflammation (Ohkusa et al., 2003). F. varium invaded host intestinal epithelial cells, significantly increased the concentrations of IL- 8 and TNF- $\alpha$, and triggered host inflammatory reactions (Ohkusa et al., 2009). Genome analysis of a $F$. varium strain showed it possesses multiple virulence factors, including type $V$ secretion system (T5SS) and Fusobacterium adhesion (FadA) paralogs, which involve in potential mucosal inflammation (Sekizuka et al., 2017).

Ruminococcus gnavus is part of the healthy gut microbiota in humans, but it is enriched in IBD (Png et al., 2010; Willing et al., 2010; Joossens et al., 2011; Nishino et al., 2018; Franzosa et al., 2019; Lloyd-Price et al., 2019). The increased level of $R$. gnavus has also been linked to spondyloarthritis (Breban et al., 2017), pouchitis in UC patients who have undergone a total colectomy (Machiels et al., 2017), and allergic diseases (Chua et al., 2018). 199 strain-specific genes involved in oxidative stress responses, adhesion, iron-acquisition, and mucus utilization were identified, potentially conferring an adaptive advantage for the $R$. gnavus clade in the IBD gut (Hall et al., 2017). R. gnavus produce and metabolize 2,7-anhydro-Neu5Ac to achieve nutritional competitive advantage in mucus against other bacteria (Tailford et al., 2015; Owen et al., 2017; Bell et al., 2019). In addition, R. gnavus synthesizes and secretes a pro-inflammatory complex polysaccharide, which potently induces TNF- $\alpha$ secretion by DCs via TLR4 (Henke et al., 2019).

Non-pylori Helicobacter also has numerous associations with IBD. In a cross-sectional study of $73 \mathrm{CD}$ and 92 controls, $C D$ is associated with the presence of enterohepatic Helicobacter spp. species DNA in intestinal biopsies (Laharie et al., 2009). Enterohepatic Helicobacter including H. hepaticus (Kullberg et al., 2001, 2006; Yang et al., 2013) and $H$. bilis (Jergens et al., 2007; Liu et al., 2011; Atherly et al., 2016) are often referred as pathobionts (Chai et al., 2017), because they have been shown to be capable of causing IBD-like disease in mice. $H$. hepaticus predominantly induces inflammatory TH17 cells in disease-susceptible IL-10-deficient animals and contributes to spontaneous colitis (Xu et al., 2018). Helicobacter pylori infection was reported to be negative associated with IBD (el-Omar et al., 1994; Sonnenberg and Genta, 2012; Rokkas et al., 2015), supporting a possible protective benefit of $H$. pylori infection against the development of IBD. Alternatively, IBD could be a protective factor against $H$. pylori infection. The presence of IBD-associated gastric mucosal lesions may create an inhospitable environment for $H$. pylori colonization (CastanoRodriguez et al., 2017).

\section{Dysbiosis in mycobiome}

Besides bacterial dysbiosis, alterations in the eukaryotic fungal community (the "mycobiome") are also important. Fungal composition in IBD is characterized with an increased Basidiomycota/Ascomycota ratio (Sokol et al., 2017), which was also skewed with higher values in CRC than control (Coker et al., 2019).

Candida spp. is significantly more abundant in patients with CD (Li et al., 2014; Lam et al., 2019) or IBD (Chehoud et al., 2015). In particular, Candida albicans were enriched in CD (Li et al., 2014), UC (Mar et al., 2016), as well as the general IBD patients (Sokol et al., 2017). Candida tropicalis are pathogenic fungus found in mouse intestine and when SPF mice were colonized with them, Clec7a(-l-) mice developed much severe colitis compared with uncolonized Clec7a(-/-) mice or colonized WT mice (lliev et al., 2012; Tang et al., 2015). These findings suggest that fungal dysbiosis is associated with IBD and that Candida species are consistently associated with the inflamed gut (Li et al., 2019). In addition, a common skin resident fungus Malassezia restricta is specifically abundant in CD patients, and exacerbates colitis in mouse models through mechanisms requiring CARD9, a signaling protein involved in antifungal immunity (Limon et al., 2019).

Additionally, there was a decreased proportion of Saccharomyces cerevisiae compared with healthy subjects in IBD (Sokol et al., 2017), and S. cerevisiae were depleted in CRC (Coker et al., 2019). S. cerevisiae UFMG A-905 showed protective potential in a murine model of acute UC (Tiago et al., 2015). S. cerevisiae CNCM I-3856 had been shown to reduce AIEC-induced ileal colitis in a mouse model, by inhibiting AIEC adhesion to enterocytes and restoring barrier function (Sivignon et al., 2015). In another study, however, S. cerevisiae colonization exacerbated intestinal disease and increased gut barrier permeability in a mouse model of colitis (Chiaro et al., 2017).

\section{Dysbiosis in virome}

Enteric virome is mainly consisted of bacteriophages. Among IBD subjects, the changes in virome composition reflected alterations in bacterial composition (Clooney et al., 2019). Caudovirales phage sequences were detected in intestinal washes and biopsy tissues of Australian pediatric CD patients (Wagner et al., 2013), and they were also observed in IBD patients from a UK cohort and two US validation cohorts (Norman et al., 2015). The abundance of intestinal Caudovirales phage families, including Siphoviridae, Myoviridae and Podoviridae, were elevated in a mouse 
model of colitis (Duerkop et al., 2018). Recent study showed phages from active UC patients induced more IFN-Y via a TLR9-dependent pathway, which is linked to aggravated intestinal inflammation and colitis (Gogokhia et al., 2019), suggesting that certain phages may trigger intestinal inflammation in the gut and contribute to IBD.

\section{THERAPEUTIC APPROACHES TARGETING MICROBIOME}

\section{Probiotics, prebiotics and postbiotics}

Probiotics are defined as live microorganisms which when administered in adequate amounts confer a health benefit on the host (Hill et al., 2014). Prebiotic is a substrate that is selectively utilized by probiotics conferring a health benefit (Gibson et al., 2017), while postbiotic is referring a bioactive molecule produced by a probiotic. American Gastroenterological Association Institute advised that probiotics may be considered for treatment of functional symptoms in IBD (Colombel et al., 2019). Probiotics could induce anti-inflammatory effects, improve (or restore) barrier function, and beneficially modulate the composition of the microbiome by inhibiting the growth of detrimental bacteria and promoting the growth of beneficial species (Abraham and Quigley, 2017).

As a prebiotic, inulin acts on IBD by retaining microbial populations, supporting epithelial barrier function, and defending against invasion and pathogens translocation (Akram et al., 2019). The probiotic cocktail VSL\#3 (a mix of 4 lactobacilli, 3 bifidobacteria and 1 strain of Streptococcus) reduced recurrence and maintain remission in patients with CD (Fedorak et al., 2015) and UC (Bibiloni et al., 2005; Miele et al., 2009). A meta-analysis showed that probiotic cocktail VSL\#3 was effective in inducing remission of active UC, and the probiotics may be as effective as 5-aminosalicylates (5ASAs) in preventing relapse of quiescent UC (Derwa et al., 2017). Moreover, probiotic Lactobacillus reuteri ATCC 55730 (Oliva et al., 2012), and E. coli strain Nissle 1917 (Scaldaferri et al., 2016; Sonnenborn, 2016) also have shown efficacy in the treatment of UC; however, a percentage of adverse events such as diarrhea and abdominal pain were reported in patients treated with E. coli strain Nissle 1917 (Kruis et al., 2004; Sassone-Corsi et al., 2016). In contrast, Lactobacillus acidophilus La-5 and Bifidobacterium animalis subsp. lactis BB-12 (Probio-Tec AB-25) was demonstrated with no significant clinical benefit in comparison with placebo for maintaining remission in patients with UC (Wildt et al., 2011). Additionally, several randomized, double-blind trials indicated administration of Lactobacillus rhamnosus in children with gastroenteritis did not have better outcomes than those who received placebo (Freedman et al., 2018; LaMont, 2018; Schnadower et al., 2018). More recently, a multi-strain probiotic (Lactobacillus rhamnosus NCIMB 30174, Lactobacillus plantarum NCIMB 30173, Lactobacillus acidophilus NCIMB 30175 and Enterococcus faecium NCIMB 30176) is associated with decreased intestinal inflammation in patients with UC, but not with CD (Bjarnason et al., 2019).

In addition to the traditional probiotics mentioned above, next-generation probiotics (NGPs) including F. prausnitzii and A. muciniphila were proposed (O'Toole et al., 2017). Oral administration of either live $F$. prausnitzii or its supernatant (containing its postbiotics) markedly reduced the severity of TNBS colitis, partly due to secreted metabolites able to block NF-KB activation and IL-8 production (Sokol et al., 2008a). C57BL/6 male mice administered A. muciniphila once daily by oral gavage for 14 days improved DSS-induced colitis, which was evidenced by colon length shortening, histopathology scores and enhanced barrier function (Bian et al., 2019). A. muciniphila or a specific outer membrane protein Amuc_1100 (as a postbiotic) blunted colitis, with a reduction in infiltrating macrophages and CD8(+) cytotoxic T lymphocytes (CTLs) in the colon (Wang et al., 2020). In addition to looking for new probiotic species, synthetic biology techniques were used to improve existing probiotics. A recent research showed an E. coli Nissle 1917 strain, engineered to secrete the curlifused trefoil factors, promotes intestinal barrier function and epithelial restitution, and enhance protective effects against colitis in mice (Praveschotinunt et al., 2019).

\section{Phage therapy}

Phages are highly specific and typically lyse a subgroup of strains within one bacterial species, indicating they have a limited impact on the overall composition of the subject's microbiome and are likely to have a better safety profile than antibiotic therapy. A randomized trial of oral T4-like coliphages or a commercial Russian coliphage product therapy in 120 children with acute bacterial diarrhea in Bangladesh did not report any adverse events but failed to improve diarrhea outcome (Sarker et al., 2016). Another two clinical trials also showed oral bacteriophage are safe in healthy children and adults (McCallin et al., 2013; Sarker et al., 2017). Though they demonstrated the safety feature of phage therapy, more knowledge is needed on in vivo phagebacterium interaction and assessing the efficacy in reducing severity of gastrointestinal diseases.

In recent years, phage therapy has re-gained attention as a therapeutic approach to combat infectious disease and non-communicable diseases. For instance, engineered phages was used for a human mycobacterial infection that are resistant to antibiotics (Dedrick et al., 2019), and phages that specifically targets cytolytic E. faecalis attenuated alcoholic liver disease in a recent study (Duan et al., 2019). AIEC are abnormally predominant on the ileal mucosa of IBD patients, and they bind to the CEACAM6 receptor expressed on the surface of epithelial cells (Barnich et al., 2007). Bacteriophages that targets AIEC reduced DSS-induced colitis symptoms on AIEC strain LF82-colonised CEABAC10 transgenic mice, expressing the human CEACAM6 receptor for AIEC, and significantly decreased the number of AIEC in 
faeces and in the adherent flora of intestinal sections (Galtier et al., 2017). Therefore, phages targeting AIEC strains are a promising new treatment for IBD.

\section{Fecal microbiota transplantation (FMT)}

FMT, where fecal microbiota from a healthy donor is transplanted into a patient's GI tract, is already a successful therapy for recurrent Clostridium difficile infection (CDI) (Hamilton et al., 2012; van Nood et al., 2013; Hvas et al., 2019). The prevailing hypothesis is that FMT might correct the dysbiosis associated with IBD, leading to a restoration of the gut microbial homeostasis (Burrello et al., 2018). The restored colon microbial community could inhibit $C$. difficile by multiple mechanisms: competition for nutrients; direct suppression by antimicrobial peptides; bile-acid-mediated inhibition of spore germination and vegetative growth; and activation of immune-mediated colonization resistance (Khoruts and Sadowsky, 2016).

It also has received extended attention in the treatment of CD (Zhang et al., 2013; Cui et al., 2015) and UC (Moayyedi et al., 2015; Paramsothy et al., 2017a, 2019). Improved remission rates for patients treated with FMT, possibly dependent on donor fecal composition, the use of multiple FMTs, and early treatment (Moayyedi et al., 2015). FMT appears effective in UC remission induction, but long-term durability and safety remain unclear (Paramsothy et al., 2017b). A significant fraction of patients with recurrent CDI have IBD, and FMT is somewhat less effective in clearing CDI from patients with IBD compared with patients without IBD (Khoruts et al., 2016).

Some key issues should be followed: FMT indications; donor selection; preparation of faecal material; clinical management and faecal delivery; registries, monitoring of outcomes and ethical issues; basic requirements for implementing an FMT centre (Cammarota et al., 2017, 2019). Moreover, the gut fungal together with viral community in donor stool may affect the FMT outcome of treating IBD. It has been reported high abundance of Candida albicans in donor stool reduce FMT efficacy in CDI (Zuo et al., 2018). And when studying viral transfer following FMT, multiple recipients from a single donor displayed highly individualised virus colonisation patterns (Draper et al., 2018).

\section{CONCLUSION AND PERSPECTIVE}

In the past decade there have been major advances in pathogenesis, pharmacological, and surgical interventions for both UC and CD. Current clinical applications for IBD diagnosis and treatment has been extensively reviewed by British Society of Gastroenterology consensus, and it highlights the importance of multidisciplinary research (Lamb et al., 2019). In this review we summarized the potential protective and causative microbial pathways and species in IBD (Fig. 1) as well as current status of therapeutic approaches targeting microbiome. Understanding of dysbiosis and the microbial pathways of specific microorganisms has suggested multiple strategies for modifying the intestinal microbiota to prevent or ameliorate IBD.

Some symbiotic organisms such as AIEC, Campylobacter concisus, Fusobacterium varium, Ruminococcus gnavus, and Helicobacter species, are often referred to as pathobionts because they may cause disease under certain conditions. For AIEC, potential therapeutic strategies include targeting bacterial colonization of gut mucosa, such as the use of phage therapy, bacteriocins and anti-adhesion molecules. Bacteroides fragilis produce PSA and sphingolipids, which regulate homeostasis and protect animals from experimental colitis. In contrast, ETBF induce IL-17 in the colon and DNA damage in colonic epithelium, promoting IBD or even FAP and CRC.

Precise targeting of the metabolic pathways that are used by harmful bacteria may provide a new strategy to treat IBD. For example, tungstate-mediated microbiota editing reduced the severity of intestinal inflammation in mouse models of colitis (Zhu et al., 2018), and oral administration of sodium tungstate inhibited molybdoenzymes selectively decreased gut colonization with genotoxin-producing Enterobacteriaceae, thus reducing carcinogenesis in mouse models of colitis-associated CRC (Zhu et al., 2019).

Prebiotics are promising approaches to modify human microbiome. In the context of IBD, dietary fibers promote a selected group of SCFA-producing strains and regulate BAs profiles. SCFAs, particularly butyrate, promote the development of Treg cells and mucus production to down-regulate inflammatory signaling pathways and to strengthen the epithelial barrier. Restoration of SCFA producers by selected dietary fibers is a promising approach for managing IBD.

Traditional probiotics including Bacillus spp., Bifidobacterium spp., Lactobacillus spp., and $S$. cerevisiae have showed variably ameliorative effects on IBD; however, the number of patients in these trails are relatively small. Additionally, the major challenge of utilization traditional probiotics is that we do not understand the precise probiotic mechanisms of these bacteria in the context of IBD. In contrast, next-generation probiotics (NGPs or sometimes called live biotherapeutics) are based on the outcomes of mechanism studies. Some F. prausnitzii, Roseburia and A. muciniphila strains represent promising next-generation probiotic candidates. Notably, a normal bacterial BAs metabolism, especially SBAs, also play an important role modulating the host immunological homeostasis. The therapeutic potential of Clostridium sporogens and other SBA producingspecies in IBD warrants additional investigations.

The safety of phages targeting intestinal pathogens is well documented for adults and children, based on data for several clinical trials in which no adverse events were reported. This is not surprising as phages are the most abundant viruses present in the human gastrointestinal tract. Phage-mediated targeting of E. faecalis ameliorated alcoholic liver disease, indicating precisely editing the intestinal microbiome is another promising direction. It would be 
Probiotics, prebiotics and postbiotics?

Potentially protective microbial pathways and species

- SCFAs production: Faecalibacterium prausnitzii and Roseburia

- Tryptophan metabolism: Clostridium sporogenes and others

- BAs metabolism: Clostridium leptum and others

- PSA production: non-toxigenic Bacteroides fragilis (NTBF)

- Amuc_1100-TLR2: Akkermansia muciniphila

Normal gut

Immunological homeostasis

- Normal SCFAs levels

- Normal tryptophan metabolism

- Normal SBAs levels

- Normal PSA levels

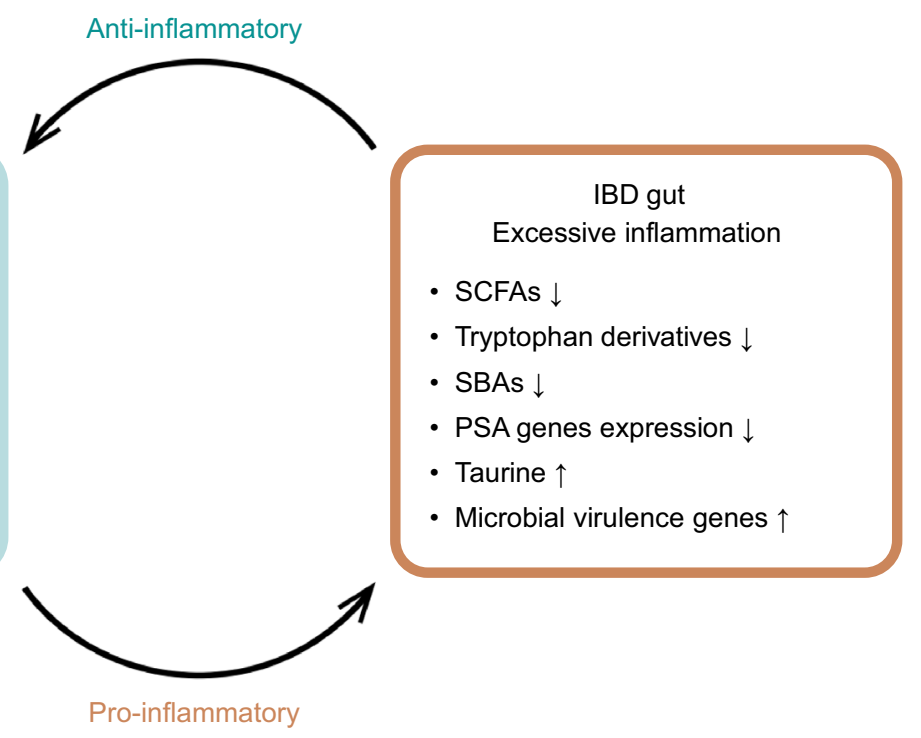

Potentially causative microbial pathways and species

- Taurine production: (species to be identified)

- Pathobionts: adherent-invasive E. coli (AIEC)

enterotoxigenic Bacteroides fragilis (ETBF)

Campylobacter concisus

Fusobacterium varium

Ruminococcus gnavus

Helicobacter hepaticus and $H$. bilis

Candida albicans

Phage therapy?

Figure 1. Graphical summary of potentially protective and causative microbial bacterial pathways and species in IBD. SCFAs, tryptophan derivatives, secondary BAs and PSA gene expression are found depleted in human IBD gut. They are also proved to have anti-inflammatory effects in biological models and therefore are often proposed as protective factors. Prebiotics, probiotics or postbiotics targeting these factors are promising strategies to alleviate IBD. In contrast, taurine is found enriched in the metabolome and virulent genes are found enriched in microbiome of human IBD gut. Taurine and the virulence-gene-containing pathobionts also have pro-inflammatory effects in biological models and therefore are proposed as potentially causative factor for IBD. Phage therapies that target these factors are promising strategies to alleviate IBD. SCFAs, short-chain fatty acids; SBAs, secondary bile acids; PSA, polysaccharide A. 
interesting to test whether IBD could be treated by phages that target potentially causative bacteria reviewed in this article including AIEC. Besides bacteria, Candida species are consistently more abundant in IBD. Mycophage that targets Candida species may inhibit their colonization and contribute to the alleviation of IBD.

FMT can be used as a therapeutic option to treat CDI in the context of IBD when first line antibiotics are ineffective. The impact of phage on microbial dynamics is a factor that should be considered. Caudovirales phage are more significantly enriched in the intestine of individuals with IBD, which supports the notion that elevated Caudovirales phages might predict FMT failure and need for additional maintenance FMT delivery or escalation of treatment. Furthermore, Candida albicans, the fungal community that are more abundant in IBD patients compared to healthy individuals, compromises FMT efficacy in a mouse model of CDI. Therefore, further research is needed to explore whether pre-FMT eradication of $C$. albicans in some recipients might increase FMT success rates in some cases. US FDA recently issued a safety alert about the potential risk of transmission of pathogenic bacteria by FMT products and the resultant serious adverse reactions that may occur. It's important to implement Shiga toxin-producing $E$. coli and enteropathogenic $E$. coli screening into the quality and safety protocols. Overall, FMT shows some evidence of benefit in IBD; however, it should only be used in the context of clinical trials until further high-quality evidence clarifies optimal administration protocol.

To conclude, we are excited to see the recent advances in microbiome research in IBD and anticipate studies in IBD pathogenesis provide more insights to facilitate therapeutic efforts to ameliorate this increasingly common disease.

\section{ACKNOWLEDGEMENTS}

We thank Drs. Xiaojian Wu, Zhen He and Jia Ke for helpful discussion. We thank Peijie Li for assisting preparation of this manuscript. This work has been supported by National Key Research and Development Program of China (No. 2017YFC1308800), the Fundamental Research Funds for the Central Universities (19ykzd33, Sun Yat-sen University) and the National Natural Science Foundation of China (Grant No. 31900056).

\section{ABBREVIATIONS}

AIEC, adherent-invasive E. coli; BAs, bile acids; BFT, B. fragilis toxin; $C D$, Crohn's disease; $C D I$, Clostridium difficile infection; CEACAM6, Carcinoembryonic antigen related cell adhesion molecule 6; CRC, colorectal cancer; DCs, dendritic cells; DSS, dextransulfate sodium; ETBF, enterotoxigenic Bacteroides fragilis; FAP, familial adenomatous polyposis; FMT, fecal microbiota transplantation; IBD, inflammatory bowel diseases; IECs, intestinal epithelial cells; IL, interleukin; LPF, long polar fimbriae; NGPs, next-generation probiotics; NTBF, non-toxigenic Bacteroides fragilis; PBAs, primary BAs; PSA, polysaccharide A; SCFAs, short-chain fatty acids; SBAs, secondary BAs; TNF, anti-tumor necrosis factor; Treg cell, regulatory T cell; T5SS, type $V$ secretion system; UC, ulcerative disease

\section{COMPLIANCE WITH ETHICS GUIDELINES}

Sheng Liu, Wenjing Zhao, Ping Lan, and Xiangyu Mou declare that they have no conflict of interest.

\section{OPEN ACCESS}

This article is licensed under a Creative Commons Attribution 4.0 International License, which permits use, sharing, adaptation, distribution and reproduction in any medium or format, as long as you give appropriate credit to the original author(s) and the source, provide a link to the Creative Commons licence, and indicate if changes were made. The images or other third party material in this article are included in the article's Creative Commons licence, unless indicated otherwise in a credit line to the material. If material is not included in the article's Creative Commons licence and your intended use is not permitted by statutory regulation or exceeds the permitted use, you will need to obtain permission directly from the copyright holder. To view a copy of this licence, visit http:// creativecommons.org/licenses/by/4.0/.

\section{REFERENCES}

Abraham BP, Quigley EMM (2017) Probiotics in inflammatory bowel disease. Gastroenterol Clin N Am 46:769-782

Agus A, Planchais J, Sokol H (2018) Gut microbiota regulation of tryptophan metabolism in health and disease. Cell Host Microbe 23:716-724

Akram W, Garud N, Joshi R (2019) Role of inulin as prebiotics on inflammatory bowel disease. Drug Discov Ther 13:1-8

Alhagamhmad MH, Day AS, Lemberg DA, Leach ST (2016) An overview of the bacterial contribution to Crohn disease pathogenesis. J Med Microbiol 65:1049-1059

An D, Oh SF, Olszak T, Neves JF, Avci FY, Erturk-Hasdemir D, Lu X, Zeissig S, Blumberg RS, Kasper DL (2014) Sphingolipids from a symbiotic microbe regulate homeostasis of host intestinal natural killer T cells. Cell 156:123-133

Ansaldo E, Slayden LC, Ching KL, Koch MA, Wolf NK, Plichta DR, Brown EM, Graham DB, Xavier RJ, Moon JJ et al (2019) Akkermansia muciniphila induces intestinal adaptive immune responses during homeostasis. Science 364:1179-1184

Arthur JC, Perez-Chanona E, Muhlbauer M, Tomkovich S, Uronis JM, Fan TJ, Campbell BJ, Abujamel T, Dogan B, Rogers AB et al (2012) Intestinal inflammation targets cancer-inducing activity of the microbiota. Science 338:120-123

Atherly T, Mosher C, Wang C, Hostetter J, Proctor A, Brand MW, Phillips GJ, Wannemuehler M, Jergens AE (2016) Helicobacter bilis infection alters mucosal bacteria and modulates colitis development in defined microbiota mice. Inflamm Bowel Dis 22:2571-2581

Barnett MP, McNabb WC, Cookson AL, Zhu S, Davy M, Knoch B, Nones K, Hodgkinson AJ, Roy NC (2010) Changes in colon gene 
expression associated with increased colon inflammation in interleukin-10 gene-deficient mice inoculated with Enterococcus species. BMC Immunol 11:39

Barnich N, Carvalho FA, Glasser AL, Darcha C, Jantscheff P, Allez M, Peeters H, Bommelaer G, Desreumaux P, Colombel JF et al (2007) CEACAM6 acts as a receptor for adherent-invasive E. coli, supporting ileal mucosa colonization in Crohn disease. J Clin Investig 117:1566-1574

Bell A, Brunt J, Crost E, Vaux L, Nepravishta R, Owen CD, Latousakis D, Xiao A, Li W, Chen X et al (2019) Elucidation of a sialic acid metabolism pathway in mucus-foraging Ruminococcus gnavus unravels mechanisms of bacterial adaptation to the gut. Nat Microbiol 4:2393-2404

Bian X, Wu W, Yang L, Lv L, Wang Q, Li Y, Ye J, Fang D, Wu J, Jiang $X$ et al (2019) Administration of Akkermansia muciniphila ameliorates dextran sulfate sodium-induced ulcerative colitis in mice. Front Microbiol 10:2259

Bibiloni R, Fedorak RN, Tannock GW, Madsen KL, Gionchetti P, Campieri M, De Simone C, Sartor RB (2005) VSL\#3 probioticmixture induces remission in patients with active ulcerative colitis. Am J Gastroenterol 100:1539-1546

Bjarnason I, Sission G, Hayee B (2019) A randomised, double-blind, placebo-controlled trial of a multi-strain probiotic in patients with asymptomatic ulcerative colitis and Crohn's disease. Inflammopharmacology 27:465-473

Blandford LE, Johnston EL, Sanderson JD, Wade WG, Lax AJ (2019) Promoter orientation of the immunomodulatory Bacteroides fragilis capsular polysaccharide A (PSA) is off in individuals with inflammatory bowel disease (IBD). Gut Microbes 10:569-577

Breban M, Tap J, Leboime A, Said-Nahal R, Langella P, Chiocchia G, Furet JP, Sokol H (2017) Faecal microbiota study reveals specific dysbiosis in spondyloarthritis. Ann Rheum Dis 76:16141622

Bringer MA, Glasser AL, Tung CH, Meresse S, Darfeuille-Michaud A (2006) The Crohn's disease-associated adherent-invasive Escherichia coli strain LF82 replicates in mature phagolysosomes within J774 macrophages. Cell Microbiol 8:471-484

Burrello C, Garavaglia F, Cribiu FM, Ercoli G, Lopez G, Troisi J, Colucci A, Guglietta S, Carloni S, Guglielmetti S et al (2018) Therapeutic faecal microbiota transplantation controls intestinal inflammation through IL10 secretion by immune cells. Nat Commun 9:5184

Cammarota G, laniro G, Tilg $H$, Rajilic-Stojanovic M, Kump P, Satokari R, Sokol H, Arkkila P, Pintus C, Hart A et al (2017) European consensus conference on faecal microbiota transplantation in clinical practice. Gut 66:569-580

Cammarota G, laniro G, Kelly CR, Mullish BH, Allegretti JR, Kassam Z, Putignani L, Fischer M, Keller JJ, Costello SP et al (2019) International consensus conference on stool banking for faecal microbiota transplantation in clinical practice. Gut 68:2111-2121

Cao X (2017) Intestinal inflammation induced by oral bacteria. Science 358:308-309

Castano-Rodriguez N, Kaakoush NO, Lee WS, Mitchell HM (2017) Dual role of Helicobacter and Campylobacter species in IBD: a systematic review and meta-analysis. Gut 66:235-249
Chai JN, Peng Y, Rengarajan S, Solomon BD, Ai TL, Shen Z, Perry JSA, Knoop KA, Tanoue T, Narushima S et al (2017) Helicobacter species are potent drivers of colonic $\mathrm{T}$ cell responses in homeostasis and inflammation. Sci Immunol 2(13):eaal5068

Chehoud C, Albenberg LG, Judge C, Hoffmann C, Grunberg S, Bittinger K, Baldassano RN, Lewis JD, Bushman FD, Wu GD (2015) Fungal signature in the gut microbiota of pediatric patients with inflammatory bowel disease. Inflamm Bowel Dis 21:19481956

Chiaro TR, Soto R, Zac Stephens W, Kubinak JL, Petersen C, Gogokhia L, Bell R, Delgado JC, Cox J, Voth W et al (2017) A member of the gut mycobiota modulates host purine metabolism exacerbating colitis in mice. Sci Transl Med 9(380):eaaf9044

Chua HH, Chou HC, Tung YL, Chiang BL, Liao CC, Liu HH, Ni YH (2018) Intestinal dysbiosis featuring abundance of Ruminococcus gnavus associates with allergic diseases in infants. Gastroenterology 154:154-167

Chung L, Thiele Orberg E, Geis AL, Chan JL, Fu K, DeStefano Shields CE, Dejea CM, Fathi P, Chen J, Finard BB et al (2018) Bacteroides fragilis toxin coordinates a pro-carcinogenic inflammatory cascade via targeting of colonic epithelial cells. Cell Host Microbe 23(203-214):e205

Clooney AG, Sutton TDS, Shkoporov AN, Holohan RK, Daly KM, O'Regan O, Ryan FJ, Draper LA, Plevy SE, Ross RP et al (2019) Whole-virome analysis sheds light on viral dark matter in inflammatory bowel disease. Cell Host Microbe 26:764-778.e765

Coker OO, Nakatsu G, Dai RZ, Wu WKK, Wong SH, Ng SC, Chan FKL, Sung JJY, Yu J (2019) Enteric fungal microbiota dysbiosis and ecological alterations in colorectal cancer. Gut 68:654-662

Colombel JF, Shin A, Gibson PR (2019) AGA clinical practice update on functional gastrointestinal symptoms in patients with inflammatory bowel disease: expert review. Clin Gastroenterol Hepatol 17:380-390.e381

Connors J, Dunn KA, Allott J, Bandsma R, Rashid M, Otley AR, Bielawski JP, Van Limbergen J (2019) The relationship between fecal bile acids and microbiome community structure in pediatric Crohn's disease. ISME J 14:702-713

Cui B, Feng Q, Wang H, Wang M, Peng Z, Li P, Huang G, Liu Z, Wu $P$, Fan $Z$ et al (2015) Fecal microbiota transplantation through mid-gut for refractory Crohn's disease: safety, feasibility, and efficacy trial results. J Gastroenterol Hepatol 30:51-58

Darfeuille-Michaud A (2002) Adherent-invasive Escherichia coli: a putative new E. coli pathotype associated with Crohn's disease. Int J Med Microbiol 292:185-193

Darfeuille-Michaud A, Boudeau J, Bulois P, Neut C, Glasser AL, Barnich N, Bringer MA, Swidsinski A, Beaugerie L, Colombel JF (2004) High prevalence of adherent-invasive Escherichia coli associated with ileal mucosa in Crohn's disease. Gastroenterology 127:412-421

De Hertogh G, Aerssens J, Geboes KP, Geboes K (2008) Evidence for the involvement of infectious agents in the pathogenesis of Crohn's disease. World J Gastroenterol 14:845-852

Dedrick RM, Guerrero-Bustamante CA, Garlena RA, Russell DA, Ford K, Harris K, Gilmour KC, Soothill J, Jacobs-Sera D, Schooley RT et al (2019) Engineered bacteriophages for treatment of a patient with a disseminated drug-resistant Mycobacterium abscessus. Nat Med 25:730-733 
Dejea CM, Fathi P, Craig JM, Boleij A, Taddese R, Geis AL, Wu X, DeStefano Shields CE, Hechenbleikner EM, Huso DL et al (2018) Patients with familial adenomatous polyposis harbor colonic biofilms containing tumorigenic bacteria. Science 359:592-597

Derwa Y, Gracie DJ, Hamlin PJ, Ford AC (2017) Systematic review with meta-analysis: the efficacy of probiotics in inflammatory bowel disease. Aliment Pharmacol Ther 46:389-400

Dickson I (2018) Gut microbiota: oral bacteria: a cause of IBD? Nat Rev Gastroenterol Hepatol 15:4-5

Dodd D, Spitzer MH, Van Treuren W, Merrill BD, Hryckowian AJ, Higginbottom SK, Le A, Cowan TM, Nolan GP, Fischbach MA et al (2017) A gut bacterial pathway metabolizes aromatic amino acids into nine circulating metabolites. Nature 551:648-652

Draper LA, Ryan FJ, Smith MK, Jalanka J, Mattila E, Arkkila PA, Ross RP, Satokari R, Hill C (2018) Long-term colonisation with donor bacteriophages following successful faecal microbial transplantation. Microbiome 6:220

Duan Y, Llorente C, Lang S, Brandl K, Chu H, Jiang L, White RC, Clarke TH, Nguyen K, Torralba M et al (2019) Bacteriophage targeting of gut bacterium attenuates alcoholic liver disease. Nature 575:505-511

Duboc H, Rajca S, Rainteau D, Benarous D, Maubert MA, Quervain E, Thomas G, Barbu V, Humbert L, Despras G et al (2013) Connecting dysbiosis, bile-acid dysmetabolism and gut inflammation in inflammatory bowel diseases. Gut 62:531-539

Duerkop BA, Kleiner M, Paez-Espino D, Zhu W, Bushnell B, Hassell B, Winter SE, Kyrpides NC, Hooper LV (2018) Murine colitis reveals a disease-associated bacteriophage community. Nat Microbiol 3:1023-1031

Eaton K, Pirani A, Snitkin ES, Reproducibility Project: Cancer B, lorns E, Tsui R, Denis A, Perfito N, Errington TM, lorns E et al (2018). Replication Study: intestinal inflammation targets cancerinducing activity of the microbiota. Elife 7:e34364.

el-Omar E, Penman I, Cruikshank G, Dover S, Banerjee S, Williams C, McColl KE (1994) Low prevalence of Helicobacter pylori in inflammatory bowel disease: association with sulphasalazine. Gut 35:1385-1388

Erickson AR, Cantarel BL, Lamendella R, Darzi Y, Mongodin EF, Pan C, Shah M, Halfvarson J, Tysk C, Henrissat B et al (2012) Integrated metagenomics/metaproteomics reveals human hostmicrobiota signatures of Crohn's disease. PLoS ONE 7:e49138

Fedorak RN, Feagan BG, Hotte N, Leddin D, Dieleman LA, Petrunia DM, Enns R, Bitton A, Chiba N, Pare P et al (2015) The probiotic VSL\#3 has anti-inflammatory effects and could reduce endoscopic recurrence after surgery for Crohn's disease. Clin Gastroenterol Hepatol 13:928-935.e922

Franzosa EA, Sirota-Madi A, Avila-Pacheco J, Fornelos N, Haiser $H J$, Reinker S, Vatanen T, Hall AB, Mallick H, Mclver LJ et al (2019) Gut microbiome structure and metabolic activity in inflammatory bowel disease. Nat Microbiol 4:293-305

Freedman SB, Williamson-Urquhart S, Farion KJ, Gouin S, Willan AR, Poonai N, Hurley K, Sherman PM, Finkelstein Y, Lee BE et al (2018) Multicenter trial of a combination probiotic for children with gastroenteritis. N Engl J Med 379:2015-2026

Furusawa Y, Obata Y, Fukuda S, Endo TA, Nakato G, Takahashi D, Nakanishi Y, Uetake C, Kato K, Kato T et al (2013) Commensal microbe-derived butyrate induces the differentiation of colonic regulatory T cells. Nature 504:446-450

Galtier M, De Sordi L, Sivignon A, de Vallee A, Maura D, Neut C, Rahmouni O, Wannerberger K, Darfeuille-Michaud A, Desreumaux $P$ et al (2017) Bacteriophages targeting adherent invasive Escherichia coli strains as a promising new treatment for Crohn's disease. J Crohns Colitis 11:840-847

Garrett WS (2019) The gut microbiota and colon cancer. Science 364:1133-1135

Garrett WS, Gallini CA, Yatsunenko T, Michaud M, DuBois A, Delaney ML, Punit S, Karlsson M, Bry L, Glickman JN et al (2010) Enterobacteriaceae act in concert with the gut microbiota to induce spontaneous and maternally transmitted colitis. Cell Host Microbe 8:292-300

Gibson GR, Hutkins R, Sanders ME, Prescott SL, Reimer RA, Salminen SJ, Scott K, Stanton C, Swanson KS, Cani PD et al (2017) Expert consensus document: The International Scientific Association for Probiotics and Prebiotics (ISAPP) consensus statement on the definition and scope of prebiotics. Nat Rev Gastroenterol Hepatol 14:491-502

Gogokhia L, Buhrke K, Bell R, Hoffman B, Brown DG, HankeGogokhia C, Ajami NJ, Wong MC, Ghazaryan A, Valentine JF et al (2019) Expansion of bacteriophages is linked to aggravated intestinal inflammation and colitis. Cell Host Microbe 25:285-299. e288

Hall AB, Yassour M, Sauk J, Garner A, Jiang X, Arthur T, Lagoudas GK, Vatanen T, Fornelos N, Wilson R et al (2017) A novel Ruminococcus gnavus clade enriched in inflammatory bowel disease patients. Genome Med 9:103

Hamilton MJ, Weingarden AR, Sadowsky MJ, Khoruts A (2012) Standardized frozen preparation for transplantation of fecal microbiota for recurrent Clostridium difficile infection. Am J Gastroenterol 107:761-767

Hang S, Paik D, Yao L, Kim E, Trinath J, Lu J, Ha S, Nelson BN, Kelly SP, Wu L et al (2019) Bile acid metabolites control TH17 and Treg cell differentiation. Nature 576:143-148

Hedin C, van der Gast CJ, Rogers GB, Cuthbertson L, McCartney S, Stagg AJ, Lindsay JO, Whelan K (2016) Siblings of patients with Crohn's disease exhibit a biologically relevant dysbiosis in mucosal microbial metacommunities. Gut 65:944-953

Henke MT, Kenny DJ, Cassilly CD, Vlamakis H, Xavier RJ, Clardy J (2019) Ruminococcus gnavus, a member of the human gut microbiome associated with Crohn's disease, produces an inflammatory polysaccharide. Proc Natl Acad Sci USA 116:12672-12677

Hill C, Guarner F, Reid G, Gibson GR, Merenstein DJ, Pot B, Morelli L, Canani RB, Flint HJ, Salminen S et al (2014) Expert consensus document. The International Scientific Association for Probiotics and Prebiotics consensus statement on the scope and appropriate use of the term probiotic. Nat Rev Gastroenterol Hepatol 11:506-514

Hvas CL, Dahl Jørgensen SM, Jørgensen SRP, Storgaard M, Lemming L, Hansen MM, Erikstrup C, Dahlerup JF (2019) Fecal microbiota transplantation is superior to fidaxomicin for treatment of recurrent Clostridium difficile infection. Gastroenterology 156:1324-1332.e1323 
Iliev ID, Funari VA, Taylor KD, Nguyen Q, Reyes CN, Strom SP, Brown J, Becker CA, Fleshner PR, Dubinsky M et al (2012) Interactions between commensal fungi and the C-type lectin receptor Dectin-1 influence colitis. Science 336:1314-1317

Imhann F, Vich Vila A, Bonder MJ, Fu J, Gevers D, Visschedijk MC, Spekhorst LM, Alberts R, Franke L, van Dullemen HM et al (2018) Interplay of host genetics and gut microbiota underlying the onset and clinical presentation of inflammatory bowel disease. Gut 67:108-119

Jergens AE, Wilson-Welder JH, Dorn A, Henderson A, Liu Z, Evans RB, Hostetter J, Wannemuehler MJ (2007) Helicobacter bilis triggers persistent immune reactivity to antigens derived from the commensal bacteria in gnotobiotic $\mathrm{C} 3 \mathrm{H} / \mathrm{HeN}$ mice. Gut 56:934940

Joossens M, Huys G, Cnockaert M, De Preter V, Verbeke K, Rutgeerts P, Vandamme P, Vermeire S (2011) Dysbiosis of the faecal microbiota in patients with Crohn's disease and their unaffected relatives. Gut 60:631-637

Kalischuk LD, Buret AG (2010) A role for Campylobacter jejuniinduced enteritis in inflammatory bowel disease? Am J Physiol Gastrointest Liver Physiol 298:29

Khoruts A, Sadowsky MJ (2016) Understanding the mechanisms of faecal microbiota transplantation. Nat Rev Gastroenterol Hepatol 13:508-516

Khoruts A, Rank KM, Newman KM, Viskocil K, Vaughn BP, Hamilton MJ, Sadowsky MJ (2016) Inflammatory bowel disease affects the outcome of fecal microbiota transplantation for recurrent Clostridium difficile infection. Clin Gastroenterol Hepatol 14:1433-1438

Kim MH, Kang SG, Park JH, Yanagisawa M, Kim CH (2013) Shortchain fatty acids activate GPR41 and GPR43 on intestinal epithelial cells to promote inflammatory responses in mice. Gastroenterology 145(396-406):e391-e310

Kirk KF, Nielsen HL, Thorlacius-Ussing O, Nielsen H (2016) Optimized cultivation of Campylobacter concisus from gut mucosal biopsies in inflammatory bowel disease. Gut Pathog 8:27

Kostic AD, Xavier RJ, Gevers D (2014) The microbiome in inflammatory bowel disease: current status and the future ahead. Gastroenterology 146:1489-1499

Kotlowski R, Bernstein CN, Sepehri S, Krause DO (2007) High prevalence of Escherichia coli belonging to the B2+D phylogenetic group in inflammatory bowel disease. Gut 56:669-675

Kruis W, Fric P, Pokrotnieks J, Lukas M, Fixa B, Kascak M, Kamm MA, Weismueller J, Beglinger C, Stolte M et al (2004) Maintaining remission of ulcerative colitis with the probiotic Escherichia coli Nissle 1917 is as effective as with standard mesalazine. Gut 53:1617-1623

Kullberg MC, Rothfuchs AG, Jankovic D, Caspar P, Wynn TA, Gorelick PL, Cheever AW, Sher A (2001) Helicobacter hepaticusinduced colitis in interleukin-10-deficient mice: cytokine requirements for the induction and maintenance of intestinal inflammation. Infect Immun 69:4232-4241

Kullberg MC, Jankovic D, Feng CG, Hue S, Gorelick PL, McKenzie BS, Cua DJ, Powrie F, Cheever AW, Maloy KJ et al (2006) IL-23 plays a key role in Helicobacter hepaticus-induced $\mathrm{T}$ celldependent colitis. J Exp Med 203:2485-2494
Laharie D, Asencio C, Asselineau J, Bulois P, Bourreille A, Moreau J, Bonjean P, Lamarque D, Pariente A, Soule JC et al (2009) Association between entero-hepatic Helicobacter species and Crohn's disease: a prospective cross-sectional study. Aliment Pharmacol Ther 30:283-293

Lam S, Zuo T, Ho M, Chan FKL, Chan PKS, Ng SC (2019) Review article: fungal alterations in inflammatory bowel diseases. Aliment Pharmacol Ther 50:1159-1171

Lamb CA, Kennedy NA, Raine T, Hendy PA, Smith PJ, Limdi JK, Hayee B, Lomer MCE, Parkes GC, Selinger C et al (2019) British Society of Gastroenterology consensus guidelines on the management of inflammatory bowel disease in adults. Gut 68:s1s106

LaMont JT (2018) Probiotics for children with gastroenteritis. N Engl J Med 379:2076-2077

Levy M, Thaiss CA, Zeevi D, Dohnalova L, Zilberman-Schapira G, Mahdi JA, David E, Savidor A, Korem T, Herzig Y et al (2015) Microbiota-modulated metabolites shape the intestinal microenvironment by regulating NLRP6 inflammasome signaling. Cell 163:1428-1443

Li Q, Wang C, Tang C, He Q, Li N, Li J (2014) Dysbiosis of gut fungal microbiota is associated with mucosal inflammation in Crohn's disease. J Clin Gastroenterol 48:513-523

Li XV, Leonardi I, lliev ID (2019) Gut mycobiota in immunity and inflammatory disease. Immunity 50:1365-1379

Limon JJ, Tang J, Li D, Wolf AJ, Michelsen KS, Funari V, Gargus M, Nguyen C, Sharma P, Maymi VI et al (2019) Malassezia is associated with Crohn's disease and exacerbates colitis in mouse models. Cell Host Microbe 25:377-388.e376

Liu Z, Ramer-Tait AE, Henderson AL, Demirkale CY, Nettleton D, Wang C, Hostetter JM, Jergens AE, Wannemuehler MJ (2011) Helicobacter bilis colonization enhances susceptibility to Typhlocolitis following an inflammatory trigger. Dig Dis Sci 56:28382848

Lloyd-Price J, Arze C, Ananthakrishnan AN, Schirmer M, AvilaPacheco J, Poon TW, Andrews E, Ajami NJ, Bonham KS, Brislawn CJ et al (2019) Multi-omics of the gut microbial ecosystem in inflammatory bowel diseases. Nature 569:655-662

Lo Presti A, Zorzi F, Del Chierico F, Altomare A, Cocca S, Avola A, De Biasio F, Russo A, Cella E, Reddel S et al (2019) Fecal and mucosal microbiota profiling in irritable bowel syndrome and inflammatory bowel disease. Front Microbiol 10:1655

Lynch SV, Pedersen O (2016) The human intestinal microbiome in health and disease. N Engl J Med 375:2369-2379

Machiels K, Joossens M, Sabino J, De Preter V, Arijs I, Eeckhaut V, Ballet V, Claes K, Van Immerseel F, Verbeke K et al (2014) A decrease of the butyrate-producing species Roseburia hominis and Faecalibacterium prausnitzii defines dysbiosis in patients with ulcerative colitis. Gut 63:1275-1283

Machiels K, Sabino J, Vandermosten L, Joossens M, Arijs I, de Bruyn M, Eeckhaut V, Van Assche G, Ferrante M, Verhaegen J et al (2017) Specific members of the predominant gut microbiota predict pouchitis following colectomy and IPAA in UC. Gut 66:7988

Mahendran V, Riordan SM, Grimm MC, Tran TA, Major J, Kaakoush NO, Mitchell H, Zhang L (2011) Prevalence of Campylobacter species in adult Crohn's disease and the preferential colonization 
sites of Campylobacter species in the human intestine. PLoS ONE 6:e25417

Mahendran V, Liu F, Riordan SM, Grimm MC, Tanaka MM, Zhang L (2016) Examination of the effects of Campylobacter concisus zonula occludens toxin on intestinal epithelial cells and macrophages. Gut Pathog 8:18

Man SM, Kaakoush NO, Leach ST, Nahidi L, Lu HK, Norman J, Day AS, Zhang L, Mitchell HM (2010) Host attachment, invasion, and stimulation of proinflammatory cytokines by Campylobacter concisus and other non-Campylobacter jejuni Campylobacter species. J Infect Dis 202:1855-1865

Mar JS, LaMere BJ, Lin DL, Levan S, Nazareth M, Mahadevan U, Lynch SV (2016) Disease severity and immune activity relate to distinct interkingdom gut microbiome states in ethnically distinct ulcerative colitis patients. mBio. https://doi.org/10.1128/mBio. 01072-16

Martin HM, Campbell BJ, Hart CA, Mpofu C, Nayar M, Singh R, Englyst H, Williams HF, Rhodes JM (2004) Enhanced Escherichia coli adherence and invasion in Crohn's disease and colon cancer. Gastroenterology 127:80-93

Martin R, Miquel S, Benevides L, Bridonneau C, Robert V, Hudault S, Chain F, Berteau O, Azevedo V, Chatel JM et al (2017) Functional characterization of novel Faecalibacterium prausnitzii strains isolated from healthy volunteers: a step forward in the use of $F$. prausnitzii as a next-generation probiotic. Front Microbiol 8:1226

Mazmanian SK, Liu CH, Tzianabos AO, Kasper DL (2005) An immunomodulatory molecule of symbiotic bacteria directs maturation of the host immune system. Cell 122:107-118

Mazmanian SK, Round JL, Kasper DL (2008) A microbial symbiosis factor prevents intestinal inflammatory disease. Nature 453:620625

McCallin S, Alam Sarker S, Barretto C, Sultana S, Berger B, Huq S, Krause L, Bibiloni R, Schmitt B, Reuteler G et al (2013) Safety analysis of a Russian phage cocktail: from metagenomic analysis to oral application in healthy human subjects. Virology 443:187196

Miele E, Pascarella F, Giannetti E, Quaglietta L, Baldassano RN, Staiano A (2009) Effect of a probiotic preparation (VSL\#3) on induction and maintenance of remission in children with ulcerative colitis. Am J Gastroenterol 104:437-443

Moayyedi P, Surette MG, Kim PT, Libertucci J, Wolfe M, Onischi C, Armstrong D, Marshall JK, Kassam Z, Reinisch W et al (2015) Fecal microbiota transplantation induces remission in patients with active ulcerative colitis in a randomized controlled trial. Gastroenterology 149:102-109.e106

Morgan XC, Tickle TL, Sokol H, Gevers D, Devaney KL, Ward DV, Reyes JA, Shah SA, LeLeiko N, Snapper SB et al (2012) Dysfunction of the intestinal microbiome in inflammatory bowel disease and treatment. Genome Biol 13:R79

Mukhopadhya I, Thomson JM, Hansen R, Berry SH, EI-Omar EM, Hold GL (2011) Detection of Campylobacter concisus and other Campylobacter species in colonic biopsies from adults with ulcerative colitis. PLoS ONE 6:e21490

Mylonaki M, Rayment NB, Rampton DS, Hudspith BN, Brostoff J (2005) Molecular characterization of rectal mucosa-associated bacterial flora in inflammatory bowel disease. Inflamm Bowel Dis 11:481-487

Nattramilarasu PK, Bucker R, Lobo de Sa FD, Fromm A, Nagel O, Lee IM, Butkevych E, Mousavi S, Genger C, Klove S et al (2020) Campylobacter concisus impairs sodium absorption in colonic epithelium via $\mathrm{ENaC}$ dysfunction and claudin-8 disruption. Int J Mol Sci 21(2):373

Ng SC, Shi HY, Hamidi N, Underwood FE, Tang W, Benchimol El, Panaccione R, Ghosh S, Wu JCY, Chan FKL et al (2018) Worldwide incidence and prevalence of inflammatory bowel disease in the 21st century: a systematic review of populationbased studies. Lancet 390:2769-2778

Ni J, Wu GD, Albenberg L, Tomov VT (2017) Gut microbiota and IBD: causation or correlation? Nat Rev Gastroenterol Hepatol 14:573-584

Nishino K, Nishida A, Inoue R, Kawada Y, Ohno M, Sakai S, Inatomi O, Bamba S, Sugimoto M, Kawahara M et al (2018) Analysis of endoscopic brush samples identified mucosa-associated dysbiosis in inflammatory bowel disease. J Gastroenterol 53:95-106

Norman JM, Handley SA, Baldridge MT, Droit L, Liu CY, Keller BC, Kambal A, Monaco CL, Zhao G, Fleshner P et al (2015) Diseasespecific alterations in the enteric virome in inflammatory bowel disease. Cell 160:447-460

Nougayrede JP, Homburg S, Taieb F, Boury M, Brzuszkiewicz E, Gottschalk G, Buchrieser C, Hacker J, Dobrindt U, Oswald E (2006) Escherichia coli induces DNA double-strand breaks in eukaryotic cells. Science 313:848-851

Ohkusa T, Sato N, Ogihara T, Morita K, Ogawa M, Okayasu I (2002) Fusobacterium varium localized in the colonic mucosa of patients with ulcerative colitis stimulates species-specific antibody. J Gastroenterol Hepatol 17:849-853

Ohkusa T, Okayasu I, Ogihara T, Morita K, Ogawa M, Sato N (2003) Induction of experimental ulcerative colitis by Fusobacterium varium isolated from colonic mucosa of patients with ulcerative colitis. Gut 52:79-83

Ohkusa T, Yoshida T, Sato N, Watanabe S, Tajiri H, Okayasu I (2009) Commensal bacteria can enter colonic epithelial cells and induce proinflammatory cytokine secretion: a possible pathogenic mechanism of ulcerative colitis. J Med Microbiol 58:535-545

Oliva S, Di Nardo G, Ferrari F, Mallardo S, Rossi P, Patrizi G, Cucchiara S, Stronati L (2012) Randomised clinical trial: the effectiveness of Lactobacillus reuteri ATCC 55730 rectal enema in children with active distal ulcerative colitis. Aliment Pharmacol Ther 35:327-334

Ossa JC, Ho NK, Wine E, Leung N, Gray-Owen SD, Sherman PM (2013) Adherent-invasive Escherichia coli blocks interferongamma-induced signal transducer and activator of transcription (STAT)-1 in human intestinal epithelial cells. Cell Microbiol 15:446-457

O'Toole PW, Marchesi JR, Hill C (2017) Next-generation probiotics: the spectrum from probiotics to live biotherapeutics. Nat Microbiol 2:17057

Owen CD, Tailford LE, Monaco S, Suligoj T, Vaux L, Lallement R, Khedri Z, Yu H, Lecointe K, Walshaw J et al (2017) Unravelling the specificity and mechanism of sialic acid recognition by the gut symbiont Ruminococcus gnavus. Nat Commun 8:2196 
Palmela C, Chevarin C, Xu Z, Torres J, Sevrin G, Hirten R, Barnich $\mathrm{N}, \mathrm{Ng} \mathrm{SC}$, Colombel JF (2018) Adherent-invasive Escherichia coli in inflammatory bowel disease. Gut 67:574-587

Paramsothy S, Kamm MA, Kaakoush NO, Walsh AJ, van den Bogaerde J, Samuel D, Leong RWL, Connor S, Ng W, Paramsothy $R$ et al (2017a) Multidonor intensive faecal microbiota transplantation for active ulcerative colitis: a randomised placebocontrolled trial. Lancet 389:1218-1228

Paramsothy S, Paramsothy R, Rubin DT, Kamm MA, Kaakoush NO, Mitchell HM, Castano-Rodriguez N (2017b) Faecal microbiota transplantation for inflammatory bowel disease: a systematic review and meta-analysis. J Crohns Colitis 11:1180-1199

Paramsothy S, Nielsen S, Kamm MA, Deshpande NP, Faith JJ, Clemente JC, Paramsothy R, Walsh AJ, van den Bogaerde J, Samuel D et al (2019) Specific bacteria and metabolites associated with response to fecal microbiota transplantation in patients with ulcerative colitis. Gastroenterology 156:1440-1454. e1442

Pittayanon R, Lau JT, Leontiadis GI, Tse F, Yuan Y, Surette M, Moayyedi $P$ (2019) Differences in gut microbiota in patients with vs without inflammatory bowel diseases: a systematic review. Gastroenterology 158(4):930-946.e1

Plovier H, Everard A, Druart C, Depommier C, Van Hul M, Geurts L, Chilloux J, Ottman N, Duparc T, Lichtenstein L et al (2017) A purified membrane protein from Akkermansia muciniphila or the pasteurized bacterium improves metabolism in obese and diabetic mice. Nat Med 23:107-113

Png CW, Linden SK, Gilshenan KS, Zoetendal EG, McSweeney CS, Sly LI, McGuckin MA, Florin TH (2010) Mucolytic bacteria with increased prevalence in IBD mucosa augment in vitro utilization of mucin by other bacteria. Am J Gastroenterol 105:2420-2428

Postler TS, Ghosh S (2017) Understanding the holobiont: how microbial metabolites affect human health and shape the immune system. Cell Metab 26:110-130

Praveschotinunt P, Duraj-Thatte AM, Gelfat I, Bahl F, Chou DB, Joshi NS (2019) Engineered E. coli Nissle 1917 for the delivery of matrix-tethered therapeutic domains to the gut. Nat Commun 10:5580

Prindiville TP, Sheikh RA, Cohen SH, Tang YJ, Cantrell MC, Silva J $\mathrm{Jr}$ (2000) Bacteroides fragilis enterotoxin gene sequences in patients with inflammatory bowel disease. Emerg Infect Dis 6:171-174

Prorok-Hamon M, Friswell MK, Alswied A, Roberts CL, Song F, Flanagan PK, Knight P, Codling C, Marchesi JR, Winstanley C et al (2014) Colonic mucosa-associated diffusely adherent afaC+ Escherichia coli expressing IpfA and pks are increased in inflammatory bowel disease and colon cancer. Gut 63:761-770

Quevrain E, Maubert MA, Michon C, Chain F, Marquant R, Tailhades J, Miquel S, Carlier L, Bermudez-Humaran LG, Pigneur B et al (2016) Identification of an anti-inflammatory protein from Faecalibacterium prausnitzii, a commensal bacterium deficient in Crohn's disease. Gut 65:415-425

Ring C, Klopfleisch R, Dahlke K, Basic M, Bleich A, Blaut M (2019) Akkermansia muciniphila strain ATCC BAA-835 does not promote short-term intestinal inflammation in gnotobiotic interleukin10-deficient mice. Gut Microbes 10:188-203
Rokkas T, Gisbert JP, Niv Y, O'Morain C (2015) The association between Helicobacter pylori infection and inflammatory bowel disease based on meta-analysis. United Eur Gastroenterol J 3:539-550

Rossi O, van Berkel LA, Chain F, Tanweer Khan M, Taverne N, Sokol H, Duncan SH, Flint HJ, Harmsen HJ, Langella P et al (2016) Faecalibacterium prausnitzii A2-165 has a high capacity to induce $\mathrm{IL}-10$ in human and murine dendritic cells and modulates T cell responses. Sci Rep 6:18507

Round JL, Lee SM, Li J, Tran G, Jabri B, Chatila TA, Mazmanian SK (2011) The Toll-like receptor 2 pathway establishes colonization by a commensal of the human microbiota. Science 332:974-977

Sarker SA, Sultana S, Reuteler G, Moine D, Descombes P, Charton F, Bourdin G, McCallin S, Ngom-Bru C, Neville Tet al (2016) Oral phage therapy of acute bacterial diarrhea with two coliphage preparations: a randomized trial in children from Bangladesh. EBioMedicine 4:124-137

Sarker SA, Berger B, Deng Y, Kieser S, Foata F, Moine D, Descombes P, Sultana S, Huq S, Bardhan PK et al (2017) Oral application of Escherichia coli bacteriophage: safety tests in healthy and diarrheal children from Bangladesh. Environ Microbiol 19:237-250

Sassone-Corsi M, Nuccio SP, Liu H, Hernandez D, Vu CT, Takahashi AA, Edwards RA, Raffatellu M (2016) Microcins mediate competition among Enterobacteriaceae in the inflamed gut. Nature 540:280-283

Scaldaferri F, Gerardi V, Mangiola F, Lopetuso LR, Pizzoferrato M, Petito V, Papa A, Stojanovic J, Poscia A, Cammarota G et al (2016) Role and mechanisms of action of Escherichia coli Nissle 1917 in the maintenance of remission in ulcerative colitis patients: an update. World J Gastroenterol 22:5505-5511

Schirmer M, Garner A, Vlamakis H, Xavier RJ (2019) Microbial genes and pathways in inflammatory bowel disease. Nat Rev Microbiol 17:497-511

Schnadower D, Tarr PI, Casper TC, Gorelick MH, Dean JM, O'Connell KJ, Mahajan P, Levine AC, Bhatt SR, Roskind CG et al (2018) Lactobacillus rhamnosus GG versus placebo for acute gastroenteritis in children. N Engl J Med 379:2002-2014

Seishima J, lida N, Kitamura K, Yutani M, Wang Z, Seki A, Yamashita T, Sakai Y, Honda M, Yamashita T et al (2019) Gutderived Enterococcus faecium from ulcerative colitis patients promotes colitis in a genetically susceptible mouse host. Genome Biol 20:252

Sekizuka T, Ogasawara Y, Ohkusa T, Kuroda M (2017) Characterization of Fusobacterium varium $\mathrm{Fv} 113-\mathrm{g} 1$ isolated from a patient with ulcerative colitis based on complete genome sequence and transcriptome analysis. PLoS ONE 12:e0189319

Sepehri S, Khafipour E, Bernstein CN, Coombes BK, Pilar AV, Karmali M, Ziebell K, Krause DO (2011) Characterization of Escherichia coli isolated from gut biopsies of newly diagnosed patients with inflammatory bowel disease. Inflamm Bowel Dis 17:1451-1463

Seregin SS, Golovchenko N, Schaf B, Chen J, Pudlo NA, Mitchell J, Baxter NT, Zhao L, Schloss PD, Martens EC et al (2017) NLRP6 protects $\| 10(-/-)$ mice from colitis by limiting colonization of Akkermansia muciniphila. Cell Rep 19:733-745 
Sinha SR, Haileselassie Y, Nguyen LP, Tropini C, Wang M, Becker LS, Sim D, Jarr K, Spear ET, Singh G et al (2020) Dysbiosisinduced secondary bile acid deficiency promotes intestinal inflammation. Cell Host Microbe 27(4):659-670.e5

Sivignon A, de Vallee A, Barnich N, Denizot J, Darcha C, Pignede G, Vandekerckove P, Darfeuille-Michaud A (2015) Saccharomyces cerevisiae CNCM I-3856 prevents colitis induced by AIEC bacteria in the transgenic mouse model mimicking Crohn's disease. Inflamm Bowel Dis 21:276-286

Sokol H, Pigneur B, Watterlot L, Lakhdari O, Bermúdez-Humarán LG, Gratadoux J-J, Blugeon S, Bridonneau C, Furet J-P, Corthier $\mathrm{G}$ et al (2008a) Faecalibacterium prausnitzii is an anti-inflammatory commensal bacterium identified by gut microbiota analysis of Crohn disease patients. Proc Natl Acad Sci USA 105:1673116736

Sokol H, Pigneur B, Watterlot L, Lakhdari O, Bermudez-Humaran LG, Gratadoux JJ, Blugeon S, Bridonneau C, Furet JP, Corthier G et al (2008b) Faecalibacterium prausnitzii is an anti-inflammatory commensal bacterium identified by gut microbiota analysis of Crohn disease patients. Proc Natl Acad Sci USA 105:1673116736

Sokol H, Seksik P, Furet JP, Firmesse O, Nion-Larmurier I, Beaugerie L, Cosnes J, Corthier G, Marteau P, Dore J (2009) Low counts of Faecalibacterium prausnitzii in colitis microbiota. Inflamm Bowel Dis 15:1183-1189

Sokol H, Leducq V, Aschard H, Pham HP, Jegou S, Landman C, Cohen D, Liguori G, Bourrier A, Nion-Larmurier I et al (2017) Fungal microbiota dysbiosis in IBD. Gut 66:1039-1048

Song X, Sun X, Oh SF, Wu M, Zhang Y, Zheng W, Geva-Zatorsky N, Jupp R, Mathis D, Benoist $C$ et al (2020) Microbial bile acid metabolites modulate gut RORgamma(+) regulatory $\mathrm{T}$ cell homeostasis. Nature 577:410-415

Sonnenberg A, Genta RM (2012) Low prevalence of Helicobacter pylori infection among patients with inflammatory bowel disease. Aliment Pharmacol Ther 35:469-476

Sonnenborn U (2016) Escherichia coli strain Nissle 1917-from bench to bedside and back: history of a special Escherichia coli strain with probiotic properties. FEMS Microbiol Lett 363(19): fnw212

Tailford LE, Owen CD, Walshaw J, Crost EH, Hardy-Goddard J, Le Gall G, de Vos WM, Taylor GL, Juge N (2015) Discovery of intramolecular trans-sialidases in human gut microbiota suggests novel mechanisms of mucosal adaptation. Nat Commun 6:7624

Tang C, Kamiya T, Liu Y, Kadoki M, Kakuta S, Oshima K, Hattori M, Takeshita K, Kanai T, Saijo S et al (2015) Inhibition of Dectin-1 signaling ameliorates colitis by inducing Lactobacillus-mediated regulatory $\mathrm{T}$ cell expansion in the intestine. Cell Host Microbe 18:183-197

Thiele Orberg E, Fan H, Tam AJ, Dejea CM, Destefano Shields CE, Wu S, Chung L, Finard BB, Wu X, Fathi $P$ et al (2017) The myeloid immune signature of enterotoxigenic Bacteroides fragilisinduced murine colon tumorigenesis. Mucosal Immunol 10:421433

Tiago FC, Porto BA, Ribeiro NS, Moreira LM, Arantes RM, Vieira AT, Teixeira MM, Generoso SV, Nascimento VN, Martins FS et al (2015) Effect of Saccharomyces cerevisiae strain UFMG A-905 in experimental model of inflammatory bowel disease. Benef Microbes 6:807-815

Underwood AP, Kaakoush NO, Sodhi N, Merif J, Seah Lee W, Riordan SM, Rawlinson WD, Mitchell HM (2016) Campylobacter concisus pathotypes are present at significant levels in patients with gastroenteritis. J Med Microbiol 65:219-226

van Nood E, Vrieze A, Nieuwdorp M, Fuentes S, Zoetendal EG, de Vos WM, Visser CE, Kuijper EJ, Bartelsman JF, Tijssen JG et al (2013) Duodenal infusion of donor feces for recurrent Clostridium difficile. N Engl J Med 368:407-415

Vich Vila A, Imhann F, Collij V, Jankipersadsing SA, Gurry T, Mujagic Z, Kurilshikov A, Bonder MJ, Jiang X, Tigchelaar EF et al (2018) Gut microbiota composition and functional changes in inflammatory bowel disease and irritable bowel syndrome. Sci Transl Med 10(472):eaap8914

Wagner J, Maksimovic J, Farries G, Sim WH, Bishop RF, Cameron DJ, Catto-Smith AG, Kirkwood CD (2013) Bacteriophages in gut samples from pediatric Crohn's disease patients: metagenomic analysis using 454 pyrosequencing. Inflamm Bowel Dis 19:15981608

Wang L, Tang L, Feng Y, Zhao S, Han M, Zhang C, Yuan G, Zhu J, Cao S, Wu Q et al (2020) A purified membrane protein from Akkermansia muciniphila or the pasteurised bacterium blunts colitis associated tumourigenesis by modulation of CD8(+) T cells in mice. Gut. https://doi.org/10.1136/gutjnl-2019-320105

Wick EC, Rabizadeh S, Albesiano E, Wu X, Wu S, Chan J, Rhee KJ, Ortega G, Huso DL, Pardoll D et al (2014) Stat3 activation in murine colitis induced by enterotoxigenic Bacteroides fragilis. Inflamm Bowel Dis 20:821-834

Wildt S, Nordgaard I, Hansen U, Brockmann E, Rumessen JJ (2011) A randomised double-blind placebo-controlled trial with Lactobacillus acidophilus La- 5 and Bifidobacterium animalis subsp. lactis BB-12 for maintenance of remission in ulcerative colitis. J Crohns Colitis 5:115-121

Williams BB, Van Benschoten AH, Cimermancic P, Donia MS, Zimmermann M, Taketani M, Ishihara A, Kashyap PC, Fraser JS, Fischbach MA (2014) Discovery and characterization of gut microbiota decarboxylases that can produce the neurotransmitter tryptamine. Cell Host Microbe 16:495-503

Willing BP, Dicksved J, Halfvarson J, Andersson AF, Lucio M, Zheng Z, Jarnerot G, Tysk C, Jansson JK, Engstrand L (2010) A pyrosequencing study in twins shows that gastrointestinal microbial profiles vary with inflammatory bowel disease phenotypes. Gastroenterology 139:1844-1854.e1841

Wlodarska M, Luo C, Kolde R, d'Hennezel E, Annand JW, Heim CE, Krastel P, Schmitt EK, Omar AS, Creasey EA et al (2017) Indoleacrylic acid produced by commensal Peptostreptococcus species suppresses inflammation. Cell Host Microbe 22:25-37. e26

Xu M, Pokrovskii M, Ding Y, Yi R, Au C, Harrison OJ, Galan C, Belkaid Y, Bonneau R, Littman DR (2018) c-MAF-dependent regulatory $T$ cells mediate immunological tolerance to a gut pathobiont. Nature 554:373-377

Yang I, Eibach D, Kops F, Brenneke B, Woltemate S, Schulze J, Bleich A, Gruber AD, Muthupalani S, Fox JG et al (2013) Intestinal microbiota composition of interleukin-10 deficient 
C57BL/6J mice and susceptibility to Helicobacter hepaticusinduced colitis. PLoS ONE 8:e70783

Yilmaz B, Juillerat $P$, Oyas O, Ramon C, Bravo FD, Franc $Y$, Fournier N, Michetti P, Mueller C, Geuking M et al (2019) Microbial network disturbances in relapsing refractory Crohn's disease. Nat Med 25:323-336

Zamani S, Hesam Shariati S, Zali MR, Asadzadeh Aghdaei H, Sarabi Asiabar A, Bokaie S, Nomanpour B, Sechi LA, Feizabadi MM (2017) Detection of enterotoxigenic Bacteroides fragilis in patients with ulcerative colitis. Gut Pathog 9:53

Zelante T, lannitti RG, Cunha C, De Luca A, Giovannini G, Pieraccini G, Zecchi R, D'Angelo C, Massi-Benedetti C, Fallarino F et al (2013) Tryptophan catabolites from microbiota engage aryl hydrocarbon receptor and balance mucosal reactivity via interleukin-22. Immunity 39:372-385

Zhang L, Man SM, Day AS, Leach ST, Lemberg DA, Dutt S, Stormon M, Otley A, O'Loughlin EV, Magoffin A et al (2009) Detection and isolation of Campylobacter species other than C. jejuni from children with Crohn's disease. J Clin Microbiol 47:453-455
Zhang FM, Wang HG, Wang M, Cui BT, Fan ZN, Ji GZ (2013) Fecal microbiota transplantation for severe enterocolonic fistulizing Crohn's disease. World J Gastroenterol 19:7213-7216

Zhang L, Lee H, Grimm MC, Riordan SM, Day AS, Lemberg DA (2014) Campylobacter concisus and inflammatory bowel disease. World J Gastroenterol 20:1259-1267

Zhu W, Winter MG, Byndloss MX, Spiga L, Duerkop BA, Hughes ER, Buttner L, de Lima Romao E, Behrendt CL, Lopez CA et al (2018) Precision editing of the gut microbiota ameliorates colitis. Nature 553:208-211

Zhu W, Miyata N, Winter MG, Arenales A, Hughes ER, Spiga L, Kim $J$, Sifuentes-Dominguez L, Starokadomskyy P, Gopal P et al (2019) Editing of the gut microbiota reduces carcinogenesis in mouse models of colitis-associated colorectal cancer. J Exp Med 216:2378-2393

Zuo T, Wong SH, Cheung CP, Lam K, Lui R, Cheung K, Zhang F, Tang W, Ching JYL, Wu JCY et al (2018) Gut fungal dysbiosis correlates with reduced efficacy of fecal microbiota transplantation in Clostridium difficile infection. Nat Commun 9:3663 